\title{
Proceeding
}

Supplementary Issue: Spring Conferences of Sports Science. Costa Blanca Sports Science Week, 26-28 April 2018. Calpe. Alicante, Spain

\section{Relational research on sport practice and use of video games according to gender of schoolchildren from Granada}

IRWIN ANDRÉS RAMÍREZ-GRANIZO , PEDRO VALDIVIA-MORAL, FÉLIX ZURITA-ORTEGA, JOSÉ LUIS UBAGO-JIMÉNEZ

University of Granada, Spain

\begin{abstract}
Nowadays our society lives in a technological era that has led to a "technological sedentariness" resulting in a sedentary lifestyle in children that must be tackled by means of physical activity. This research study aims to analyse the link between physical activity and the use of video games. This is a descriptive, cross-sectional and relational research project. A sample made up of 142 students aged between 10 and 12 completed a self-made questionnaire which measured both their physical activity level and their CERV (Video Game Related Experiences Questionnaire). The results obtained through research show that most students do not have any problems concerning video games, and that the use of these can also help in the prevention of sedentary habits. These results have been indicated in the discussion section, contributing to the motivation of students' in relation to Physical Education, their compromise with the physical practice and the promotion of a long-lasting healthy lifestyle. As a conclusion, the need for using tools such as active video games in order to favour healthy lifestyles and also to prevent sedentary habits is demonstrated. Key words: NEW TECHNOLOGIES, VIDEO GAMES, LEISURE TIME ACTIVITIES, PHYSICAL EDUCATION, PHYSICAL ACTIVITY LEVEL.
\end{abstract}

Cite this article as:

Ramírez-Granizo, I.A., Valdivia-Moral, P., Zurita-Ortega, F., \& Ubago-Jiménez, J.L. (2018). Relational research on sport practice and use of video games according to gender of schoolchildren from Granada. Journal of Human Sport and Exercise, 13(2proc), S495-S504. doi:https://doi.org/10.14198/jhse.2018.13.Proc2.33

Corresponding author. Department of Didactics of Musical, Plastic and Body Expression, University of Granada, Spain. E-mail: irwin@correo.ugr.es

Supplementary Issue: Spring Conferences of Sports Science. Costa Blanca Sports Science Week, 26-28 April 2018. Calpe. Alicante, Spain.

JOURNAL OF HUMAN SPORT \& EXERCISE ISSN 1988-5202

(c) Faculty of Education. University of Alicante

doi: 10.14198/jhse.2018.13.Proc2.33 


\section{INTRODUCTION}

Nowadays, the amount of time children spend practising physical activity is insufficient, compared with time dedicated to video games (Nuviala, Munguía, Fernández, Ruiz \& García, 2009). In addition, education of the body at school is also not adequate, due to the amount of time they spend sitting. It is widely known that Physical Activity is highly beneficial, both physically and mentally. Physical and sporting activity is essential in order to achieve a good quality of life during childhood, adolescence and adulthood. This research study will consider the definition of Health and Quality of Life given by the World Health Organisation, defined as "An individual's perception of their position in life in the context of the culture and value systems in which they live and in relation to their goals, expectations, standards and concerns". The most important aspect of people's quality of life is the diversity of needs they require and subsequently meeting them (Bendikova \& Bartik, 2015). Research such as that by Viscarro, Cañabete, Güel, Martínez \& Cachón (2014), shows the physical, biological, mental, social and therapeutic benefits of a regular practice of physical activity, from the point of view of health sciences. Research studies such as those by Silva, Matías, Viana \& Andrade (2012) have demonstrated that men are involved in physical activity to a greater extent than women, who abandon physical activity more easily (Inchley, Kirby \& Currie, 2011). For this reason, Physical Education professionals can convey principles and values to teenagers, promoting a more active lifestyle based on healthy habits (Williams \& Mummery, 2015).

Incorporation of new technologies has been marked as one of the reasons why sedentariness has increased, since the amount of time children spend using passive digital leisure and playing video games has increased in the last years. Therefore, time invested playing video games negatively affects their health. For this reason it is important to know what is referred to as video games, what typologies exist, how to use them and what can be done in order to take advantage of these new technologies effectively.

A video game is an electronic device that enables, by means of appropriate controls, the simulation of games on television or computer screens. Many companies such as Nintendo, Sony and Microsoft produce most of these game consoles and quickly innovate their products. Chamarro et al. (2012) and López (2012) define video games as "leisure electronic devices which offer their users different game options by means of screens and peripherals". As a matter of fact, these new technologies have had a major role in these last decades (Castro, Martínez, Zurita, Chacón, Espejo \& Cabrera, 2015).

According to Belli \& López-Raventós (2008), video games can be presented in different ways. On the one hand there are dynamic personal consoles, such as Nintendo's Game Boy and Sony's Playstation Portable, which can be carried from one place to another. On the other hand there are Nintendo's Wii, Microsoft's Xbox One and Sony's Playstation 4. However, video games have also posed sedentariness as one of the main problems in society, since they replace physical activity in our free time with the use of new technologies (computer, video games, TV, etc...).

The reason being is that the abuse of these devices can cause problems and create habits difficult to eliminate at a cognitive, physical and social level (Chacón et al, 2017). Over the years it has been observed that there are increasingly fewer boys and girls who play in the street, being only visible in small villages. This is due in part to the fact that in centralised cities children prefer staying at home in front of a screen playing video games. Additionally, the fact that it is becoming more dangerous for the children to play alone in the street contributes to parents not allowing them to go outside and play. In relation to this, the expression "Technological Sedentariness" appears, referring to the massive use of new technologies in daily life and in our homes, which replaces the practice of physical activity in our free time (Duque \& Vásquez, 2013). 
There is a clear distinction between the two kinds of current video games, active ones and passive ones. Passive video games are controlled by manual coordination in order to interact with the electronic device. This is usually done in a passive posture (sitting on the sofa) where little movement is involved. These kind of games are the most widely criticised due to their favouring of sedentariness since there is little movement and little caloric expenditure, which are both necessary for a healthy life. Authors such as Moncada \& Chacón (2012) note that excessive use of video games is also associated with having sedentary parents with few rules regarding use of new technologies. On the other hand there are active video games, which enable users to interact physically, using their limbs or whole body, coinciding with images on the screen. Being successful in these kinds of games depends on moving accordingly in a given order and time in front of a camera or sensor sensitive to pressure or a modified ergometer (Foley \& Maddison, 2010). Other research studies such as those by He, Piche, Beynon \& Harris (2010) note that active video games are electronic games which enable players to act by physically using hands, legs, arms or the whole body. Being successful will depend on factors such as correct movement captured by a camera, an infrared sensor, a laser, or a floor cover sensitive to pressure (Moncada \& Chacón, 2012). Numerous studies promote the use of new technologies in education generally and more specifically in the practice of physical activity. One such study carried out by Díaz (2011) shows, from an overall educational context, that today's society is increasingly immersing itself in the field of Information and Communication Technology (ICT), including video games. Therefore, as an alternative for any teacher, Díaz (2011) as well as Eguía, Contreras \& Solano (2012) consider video games as educational instruments, despite their negative elements, promoting fun and entertainment. In the context of Physical Activity, active video games can be used as tools if they adjust to Physical Education contents. Platforms such as Kinect involve light exercise, movement of the body and the promotion of some contents related to the field (psychomotor development, knowledge of the rules of sport). From a physiological point of view, active video games can provide resources in order to work on specific Physical Education contents. Studies such as the one by Barbany (2002), show an increase in heart rate, as well as in oxygen consumption and caloric expenditure in participants, caused as a result of movement and play, associating the use of these video games with fighting against high levels of idleness and sedentariness (Gogle, Miltenberger, Graves \& Koehler, 2010). As aforementioned, these new tools can be used in order to encourage a healthier lifestyle, as well as to try to introduce physical education to children through the use of video games. Currently, technology has advanced so much that these tools have even reached schools, bringing a great deal of advantages and therefore facilitating the work of Physical Education teachers. Additionally, this subject is in charge of developing motor skills and the acquisition of elements that can help personal development and a clear quality of life, being able to respond to these requirements with the technological advances developed recently. Studies such as those by Tejero, Balsalobre, Higueras (2011), verify that $57 \%$ of the games sold in Spain are in the ACTIVE DIGITAL LEISURE category, which consist in the practice of physical activity as a means of control and interaction with video games. Moreover, in research by Fernández-Feijóo (2012), schoolchildren preferred video games related to sports and multi-platform games. In a focal group study where seven children and four adults took part (Dixon et al., 2010) participants reached the conclusion that active video games help increase the amount of physical activity and improve physical condition or fitness.

The aims of this research study are the following:

a) Establish the amount of physical activity practised by a segment of infant population in the province of Granada.

b) Know the frequency and problematic use of video games in the aforementioned sample.

c) Associate the degree of physical activity of the participants with problematic use of video games. 


\section{METHOD}

\section{Design}

The characteristics of this study are its descriptive design and cross-sectional nature. The design has also been analytical and relational due to the connections between all variables.

\section{Participants}

142 Primary Education pupils have taken part in this research study, all of them in the third stage of Primary Education. In order to choose them, a random selection between schools in general was performed, subsequently choosing those who answered positively. The chosen schools are all located in the city of Granada. $52.1 \%(n=74)$ of the participants are male and $47.9 \%(n=68)$ female, aged between 10 and 12 $(\mathrm{M}=11.07)$.

Table 1. Features of the sample

\begin{tabular}{llll}
\hline & & N & $\%$ \\
\hline \multirow{2}{*}{ Gender } & Male & 74 & 52.1 \\
& Female & 68 & 47.9 \\
\hline
\end{tabular}

\section{Instruments and variables}

Variables used in this study and which have formed part of the questionnaires are: gender, age, practice of physical activity (at least three hours per week outside the school), practice of physical activity with the family, if he or she is federated or not and video games and new technologies (referred to use and number of consoles owned by them).

Instruments used in the research study are the following:

a) Ad-hoc self-made questionnaire, with questions related to the aforementioned variables.

b) CERV questionnaire which measures behaviour related to problematic use of video games, such as time spent playing video games or the number of consoles they have. This questionnaire is a version of other popular ones such as CERY and CERM by Beranuy Chamarro Graner and Carbonell (2009). It is made up of 17 items where the answers are categorised in a Likert scale with four points and categorised in 3 levels (no problems, potential problems and severe problems).

\section{Procedure}

Firstly, permission was requested from the schools where we planned to carry out the research project. In the Education Faculty of the University of Granada, the department of Didactics of Music, Plastic and Corporal Expression wrote an explanatory letter giving details about the aim and nature of the study. A questionnaire for the students was elaborated in order to collect data, establishing a specific timetable for the application of the questionnaires (physical education class). Then, the questionnaire was administered being the teacher or the survey taker constantly available. In this research study, the participants' right to confidentiality was observed keeping personal data anonymous in order to preserve identity. Once research was completed, a report was handed in to the schools indicating the results obtained after data analysis. 


\section{Data analysis}

Program SPSS 22.0 was used, a wide and flexible system used for statistical analysis and information management capable of working with data in different formats, using them for descriptive statistical analysis.

\section{RESULTS}

As results show, most of the participants' parents practise physical activity at least three hours a week (78.9\% $n=112)$ followed by those who do not $(21,1 \% n=30)$. Likewise, most of the participants practise more than three hours of physical activity a week with a $(66.20 \% n=94)$ in contrast to $(33.8 \% n=48)$ of those who do not spend that amount of time per week. We have noticed that most of the participants are not federated $(54.9 \%$ $n=78)$, and $45 \%(n=64)$ federated.

Table 2. Physical and sporting activity practice

\begin{tabular}{lcccc}
\hline & & N & $\%$ \\
\hline Family Physical Activity & Yes & 112 & 78.9 \\
(3h/week) & No & 30 & 21.1 \\
Level of Physical Activity & & More than 3h week & 94 & 66.20 \\
& & Less than 3h week & 48 & 33.8 \\
Federated or not & Yes & 64 & 45.1 \\
& No & 78 & 54.9 \\
\hline
\end{tabular}

Additionally, we can also see that $71 \%$ of the participants $(n=101)$ have no problem related to the use of video games, whereas $26.1 \%$ of them $(n=37)$ show potential problems and only $2.8 \%$ of the schoolchildren $(n=4)$ show severe problems.

Table 3. Use of video games

\begin{tabular}{llll}
\hline & N & $\%$ \\
\hline \multirow{3}{*}{ Typology of the problems } & No problems & 101 & 71.1 \\
& Potential Problems & 37 & 26.1 \\
& Severe Problems & 4 & 2.8 \\
\hline
\end{tabular}

Regarding the relationship between gender and physical activity it has been observed that males stand out in all variables (family physical activity, more than three hours practice and federation) in contrast to females. 
Table 4. Relation between gender and physical activity

\begin{tabular}{|c|c|c|c|c|}
\hline & & \multicolumn{3}{|c|}{ Gender } \\
\hline & & Male & Female & Total \\
\hline \multirow[t]{2}{*}{ Parents' physical activity } & Yes & 59 & 53 & 112 \\
\hline & No & 15 & 15 & 30 \\
\hline Total & & 74 & 68 & 142 \\
\hline \multirow[t]{2}{*}{ More than 3 hours/week practice } & Yes & 54 & 40 & 94 \\
\hline & No & 20 & 28 & 48 \\
\hline Total & & 74 & 68 & 142 \\
\hline \multirow[t]{2}{*}{ Federated or not } & Yes & 39 & 25 & 64 \\
\hline & No & 35 & 43 & 78 \\
\hline Total & & 74 & 68 & 142 \\
\hline
\end{tabular}

As regards the relation between gender and problematic use of video games, more than two thirds do not present problems when using video games. Severe problems stand out in females $(\mathrm{N}=3)$ in comparison with males $(\mathrm{N}=1)$. By contrast, boys present a higher index $(\mathrm{N}=29)$ in the category of potential problems compared to girls $(N=8)$.

Table 5. Relation between gender and problematic use of videogames

\section{Gender}

\begin{tabular}{lllll}
\hline & Male & Female & Total \\
No problems & 44 & 57 & 101 \\
& Potential Problems & 29 & 8 & 37 \\
& Severe Problems & 1 & 3 & 4 \\
Total & & 74 & 68 & 142 \\
\hline
\end{tabular}

If we observe the relation between physical activity and problematic use of video games we can see that most of the participants who practise physical activity more than three hours per week or who are federated do not present any problem using these platforms. 
It should be noted that in the category of potential problems, respondents who practise physical activity are more than those who do not. Finally, in the category of severe problems, most respondents practise no activity at all.

Table 6. Relation between physical activity and use of video games

\begin{tabular}{|c|c|c|c|c|c|}
\hline & & \multicolumn{4}{|l|}{ CERV } \\
\hline & & No & Potential & Severe & \\
\hline & & problems & Problems & Problems & Tolar \\
\hline \multirow[t]{3}{*}{ Family Physical Activity } & Yes & 81 & 30 & 1 & 112 \\
\hline & No & 20 & 7 & 3 & 30 \\
\hline & Total & 101 & 37 & 4 & 142 \\
\hline More than 3 hours ph. & Yes & 67 & 27 & 0 & 94 \\
\hline \multirow[t]{2}{*}{ activity } & No & 34 & 10 & 4 & 48 \\
\hline & Total & 101 & 37 & 4 & 142 \\
\hline \multirow[t]{3}{*}{ Federated or not } & Yes & 45 & 19 & 0 & 64 \\
\hline & No & 56 & 18 & 4 & 78 \\
\hline & Total & 101 & 37 & 4 & 142 \\
\hline
\end{tabular}

\section{DISCUSSION}

This research study reveals that the students' parents practise a suitable level or enough hours of physical activity. This could motivate their children to practise, with their parents or alone, activities that could prevent sedentariness. This is reflected in the research study since more than half of the participants practise at least 3 hours of physical activity per week (Zurita-Ortega, Fernández-García, Cepero-González, Zagalaz-Sanchez, Valverde-Cepeda \& Ramírez-Dominguez, 2009). However, a large number of them are not federated in any sport. The reason could be that children spend the evening doing homework, studying or attending school or after-school activities, thus having little time for their hobbies (Castro, Martínez, Zurita, Chacón, Espejo \& Cabrera, 2015). It is noted that seven out of ten children do not present any problems regarding the use of video games and that these can be useful as tools to control the high levels of sedentariness existing nowadays. Therefore, using active video games and following some initiatives such as those proposed by the authors Best (2013) and Fogel, Miltenberger, Graves \& Koehler (2010,) hours of daily exercise could be complemented so as to increase caloric expenditure and thus favour a healthy lifestyle. On the other hand, a small minority of participants $(2.8 \%)$ presented potential problems while playing with these devices. This can be due to hormonal changes produced by video games, such as those mentioned by Castro, Martínez, Zurita, Chacón, Espejo, \& Cabrera (2015). The reason might be that video games increase the level of the 
player's testosterone when winning, as well as increasing cortisol (the stress hormone), thus producing negative effects on health. Although the use of these active video games has been promoted in order to lose weight and increase caloric expenditure, the conclusion is that the interest of participants who suffer overweight and use these video games drops sharply after 12 weeks. This research project pursues the same objectives as other studies with similar samples (Aguilar Cordero et al., 2011; Daley, 2009; Trujillo, Muñoz \& Villada, 2013; Staiano \& Calbert, 2011), all of them aimed at finding ideas in order to fight against sedentariness and childhood obesity.

Once all the variables were analysed, relations between them were established. Initially, students' gender and physical activity were contrasted. It was verified that boys have a higher tendency towards practising physical activity than girls. Boys practise more sports than girls, doing it more frequently and in longer sessions. Studies such as those by Matos et al. (2014) got higher percentages for females when the duration of the practice of sport was between 30 minutes and one hour, as opposed to men, who practised for a longer period, usually more than an hour. Additionally other studies state that women give up the practice of sport for sociocultural reasons, generating situations of discrimination (Gil-Madrona, Cachón-Zagalaz, DiazSuarez, Valdivia-Moral \& Zagalaz-Sánchez, 2014). Other studies such as the one by Moncada \& Chacón (2012) measure caloric expenditure and motivation of the participants (13 schoolchildren with overweight problems and 11 with normal weight) playing an active video game and a passive video game. It was demonstrated that caloric expenditure was higher in the active game also being more motivating than the passive one used by children with normal weight. Regarding the relation between physical activity and problematic use of video games, it was observed that a big part of the students had no problem with their use, coinciding with those who practised more physical activity. By contrast, Aranceta, Pérez, Ribas \& Serra (2005) state that passive video games favour a sedentary lifestyle and produce high levels of obesity and sedentariness due to the excessive time children spend playing with these devices (Amigo, Busto, Rodríguez \& Fernández, 2008).

\section{CONCLUSIONS}

As main conclusions we can point out that almost three quarters of the sample did not present any problem regarding the use of leisure electronic devices. Therefore, only two out of ten students presented potential problems and a small percentage significant problems. As regards level of physical activity, six out of ten participants practised exercise more than three hours a week, as much in federated teams as in after-school activities or just as a hobby, despite half the respondents not being federated in any sport club. This reveals the importance of sport at these ages when an early adherence will imply the practice in their adulthood. Concerning relational research regarding gender, it was established that male participants have higher levels of participation in physical activities, however achieving females quite similar scores. Finally it has been verified that video games have an important role in the life of respondents. Active video games can help reduce levels of obesity and fight against childhood sedentariness. Thus, these devices can be used as useful and harmless tools in interventions against childhood sedentariness, providing more hours of physical activity in schoolchildren.

\section{REFERENCES}

Aguilar Cordero, M. J., González Jiménez, E., García García, C. J., García López, P.A., Álvarez Ferre, J., Padilla López, C. A., ... Ocete Hita, E. (2011). Obesidad de una población de escolares de Granada: evaluación de la eficacia de una intervención educativa. Nutrición Hospitalaria, 26(3), 636641. 
Amigo, I., Busto, R., Rodríguez, J. y Fernández, C. (2008). Actividad física, ocio sedentario, falta de sueño y sobrepeso infantil. Psicothema, 20(40), 516-520.

Aranceta, J., Pérez, C., Ribas, L. y Serra, L. (2005). Epidemiología y factores determinantes de la obesidad infantil y juvenil en España. Revista Pediatría Atención Primaria, 7, 13-20.

Barbany, J. R. (2002). Fisiología del ejercicio físico y del entrenamiento. Barcelona: Editorial Paidotribo.

Belli, S. y López-Raventos, C. (2008). Breve historia de los videojuegos. Athenea Digital, 14, 159-179. https://doi.org/10.5565/rev/athenead/v0n14.570

Bendikova, E. y Bartik, P. (2015). Selected determinants of seniors' lifestyle. Journal of Human Sport and Exercise, 10(3), 805-814. https://doi.org/10.14198/hse.2015.103.06

Beranuy, M., Chamarro, A., Graner, C., y Carbonell, X. (2009). Validación de dos escalaras breves para evaluar la adicción a Internet y el abuso de móvil. Psichothema, 21, 480-485.

Best, J. (2013). Exergaming in youth: Effects on physical and cognitive health. Zeitschrifffür Physcologie, 221(2), 72-78. https://doi.org/10.1027/2151-2604/a000137

Castro, M., Martínez, A., Zurita, F., Chacón, R., Espejo, T. y Cabrera, A. (2015). Uso de Videojuegos y relación con las conductas sedentarias en una población escolar y universitaria. Journal for Educators, Teachers and Trainers, 6(1), 4051.

Castro, M., Martínez, A., Zurita, F., Chacón, R., Espejo, T. y Cabrera, A. (2015). Uso de videojuegos y su relación con la conductas sedentarias en una población escolar y universitaria: Journal for Educators, Teachers and Trainers, 6(1), 40-51.

Daley, A. J. (2009). Can exergaming contribute to improving physical activity levels and health outcomes in children? Pediatrics, 124(2), 763-771. https://doi.org/10.1542/peds.2008-2357

Díaz, V. M. (2011). La perspectiva educativa de los videojuegos, una realidad tangible. Revista Digital de Investigación Educativa Conect@s, 2(2).

Dixon, R. Maddison, R., Ni Mhurchu, C., Jull, A., Meagher-Lundberg, P., y Widdowson, D. (2010). Parent's and children's perceptions of active video games: a focus group study. Journal of Child Health Care, 14(2), 189-199. https://doi.org/10.1177/1367493509359173

Duque, E. y Vásquez, A. (2013). NUI para la educación. Eliminando la discriminación tecnológica en la búsqueda de la Inclusión Digital. Centro de Investigaciones, Corporación Universitaria Americana.

Eguía, J. L., Contreras, R. S. y Solano, L. (2012). Videojuegos: conceptos, historia y su potencial como herramienta para la educación. 3C TIC, 1(2).

Fernández-Feijóo, B. (2012). La infancia ante las pantallas: los videojuegos que entretienen a los niños gallegos de último curso de primaria. III Congreso Internacional Comunicación 3.0: La Media Enterprises y las Industrias Culturales, Investigara la Comunicación y los Nuevos Medios. Congreso Dirigido por la Universidad de Salamanca.

Fogel, V. A., Miltenberger, R. G., Graves, R. y Koehler, S. (2010). The effects of exergaming on physical activity among inactive children in a physical education classroom. Journal of applied behavior Analysis, 43(4), 591-600. https://doi.org/10.1901/jaba.2010.43-591

Foley, L. y Maddison, R. (2010). Use of active video games to increase physical activity in children: a (virtual) reality? Pedriatric Exercise Science, 22(1), 7-20. https://doi.org/10.1123/pes.22.1.7

Gil-Madrona, P., Cachón-Zagalaz, J., Diaz-Suarez, A., Valdivia-Moral, P. y Zagalaz-Sánchez, M. L. (2014). Las niñas también quieren jugar: la participación conjunta de niños y niñas en actividades no organizadas en el contexto escolar. Revista Movimiento, 20(1), 103-124.

$\mathrm{He}$, M., Piche, L., Beynon, C., y Harris, S. (2010). Screen-related sedentary behaviors: Children's and parents 'attitudes, motivations, and practices. Journal of Nutrition Education and Behavior, 42(1), 1725. https://doi.org/10.1016/i.jneb.2008.11.011

Inchley, J., Kirby, J. y Currie, C. (2011). Longitudinal Changes in Physical SelfPerceptions and Associations with Physical Activity during Adolescence. Human Kinetics Journals, 23(2), 237-249. 
Matos, L. R., Fontes, R. y De-Bortoli, R. (2014). Características de la práctica de actividades físicas y deportivas en preadolescentes en Aracaju. Revistas de Ciencias del Ejercicio y la Salud, 12(2), 1528.

Moncada, J. y Chacón, Y. (2012). El efecto de los videojuegos en variables sociales, psicológicas, y fisiológicas en niños y adolescentes. Retos, 21, 43-49.

Nuviala Nuviala, A., Munguía Izquierdo, D., Fernández Martínez, A., Ruiz Juan, F., \& García Montes, M. (2009). Typologies of occupation of leisure-time of Spanish adolescents: The case of the participants in physical activities organized. Journal of Human Sport and Exercise, 4(1), 29-39. https://doi.org/10.4100/ihse.2009.41.04

Silva, R. B., Matías, T. S., Viana, M. S. y Andrade, A. (2012). Relacao da prática de exercicios físicos e factores asociados asregulacoesmotivacionais de adolescentes brasileiros. Motricidades, 8(2), 821.

Staiano, A. E. y Calvert, S. L. (2011). Exergames for physical education courses: Physical, social, and cognitive benefits. Child development perspectives, 5(2), 93-98. https://doi.org/10.1111/j.17508606.2011.00162.x

Tejero, C. M., Balsalobre, C. e Higueras, E. (2011). Active Digital Entertainment (ADE). Social reality, treats and opportunities of virtual physical activity. Journal of Sport and Health Research, 3(1), 7-16.

Trujillo, J.C. G., Muñoz, J. E., y Villada, J. F. (2013). Exergames: una herramienta tecnológica para la actividad física. Revista Médica de Risaralda, 19(2), 126-130.

Viscarro, I., Cañabate, D., Güel, R., Martínez, M. A. y Cachón, J. (2014). Psychomotor content and its contribution to the healthy habits formation in childhood. Journal of Sport and Health Research, 6(1), 99-106.

Williams, S. y Mummery, W. (2015). We can do that! Collaborative assessment of school environments to promote healthy adolescent nutrition and physical activity behaviors. Health Education Research, 30(2), 272-284. https://doi.org/10.1093/her/cyv007

Zurita, F., Fernández, R., Rojas, J. y Cepero, M. (2010). Lateralidad manual y variables geográficas, antropométricas, funcionales y raquídeas. Revista Internacional de Medicina y Ciencias de la Actividad Física y el Deporte, 10(39), 439-457.

Zurita-Ortega, F., Fernández-García, R., Cepero-González, M., Zagalaz-Sánchez, M. L., ValverdeCepeda, M. y Ramírez-Domínguez, P. (2009). The relationship between pain and physical activity in older adults that begin a program of physical activity. Journal of Human Sport and Exercise, 4(3), 284-297. https://doi.org/10.4100/jhse.2009.43.10

\section{(2) $\mathbb{Q} \Theta \Theta$}

This title is licensed under a Creative Commons Attribution-NonCommercial-NoDerivs 4.0 Unported License. 